\title{
Tropical vegetation response to Heinrich Event 1 as simulated with the UVic ESCM and CCSM3
}

\author{
D. Handiani ${ }^{1, *}$, A. Paul ${ }^{1,2}$, M. Prange ${ }^{1,2}$, U. Merkel ${ }^{1,2}$, L. Dupont ${ }^{2}$, and X. Zhang ${ }^{1}$ \\ ${ }^{1}$ Department of Geosciences, University of Bremen, Bremen, Germany \\ ${ }^{2}$ MARUM - Center for Marine Environmental Sciences, University of Bremen, Bremen, Germany \\ *now at: Japan Agency for Marine-Earth Science and Technology (JAMSTEC), Yokohama, Japan \\ Correspondence to: D. Handiani (dhandiani@marum.de)
}

Received: 12 October 2012 - Published in Clim. Past Discuss.: 5 November 2012

Revised: 5 June 2013 - Accepted: 28 June 2013 - Published: 31 July 2013

\begin{abstract}
We investigated changes in tropical climate and vegetation cover associated with abrupt climate change during Heinrich Event 1 (HE1, ca. 17.5 ka BP) using two different global climate models: the University of Victoria Earth System-Climate Model (UVic ESCM) and the Community Climate System Model version 3 (CCSM3). Tropical South American and African pollen records suggest that the cooling of the North Atlantic Ocean during HE1 influenced the tropics through a southward shift of the rain belt. In this study, we simulated the HE1 by applying a freshwater perturbation to the North Atlantic Ocean. The resulting slowdown of the Atlantic Meridional Overturning Circulation was followed by a temperature seesaw between the Northern and Southern Hemispheres, as well as a southward shift of the tropical rain belt. The shift and the response pattern of the tropical vegetation around the Atlantic Ocean were more pronounced in the CCSM3 than in the UVic ESCM simulation. For tropical South America, opposite changes in tree and grass cover were modeled around $10^{\circ} \mathrm{S}$ in the CCSM3 but not in the UVic ESCM. In tropical Africa, the grass cover increased and the tree cover decreased around $15^{\circ} \mathrm{N}$ in the UVic ESCM and around $10^{\circ} \mathrm{N}$ in the CCSM3. In the CCSM3 model, the tree and grass cover in tropical Southeast Asia responded to the abrupt climate change during the HE1, which could not be found in the UVic ESCM. The biome distributions derived from both models corroborate findings from pollen records in southwestern and equatorial western Africa as well as northeastern Brazil.
\end{abstract}

\section{Introduction}

Heinrich events in general are associated with layers of icerafted debris (IRD) in the sediments of the North Atlantic Ocean dated between $70 \mathrm{ka} \mathrm{BP}(\mathrm{ka} \mathrm{BP}=$ thousand years before present) and $14 \mathrm{ka} \mathrm{BP}$ (Heinrich, 1988; Broecker, 1994). The Heinrich event 1 (HE1, ca. $17.5 \mathrm{ka} \mathrm{BP}$ ) is the most recent of these distinctive cold periods in the North Atlantic region. Paleoceanographic evidence suggests a connection between the abrupt climate changes during these events and the variability of the North Atlantic Deep Water (NADW) formation and the Atlantic Meridional Overturning Circulation (AMOC, Sarnthein et al., 1994; McManus et al., 2004).

Frequently, a change in the AMOC during the HE1 is invoked to explain an unusual hydrological cycle in the tropics and a southward shift of the Intertropical Convergence Zone (ITCZ) and its associated rain belt (e.g., Behling et al., 2000). Since vegetation and climate are tightly coupled, tropical climate changes influence the tropical vegetation patterns. This is demonstrated by pollen proxy records, which exhibit changes in the tropics simultaneous with the North Atlantic temperature changes during the HE1 (e.g. Hessler et al., 2010). Some examples are found in eastern tropical Africa (Kashiru swamp, Burundi), where grassland and dry shrubland occurred due to a fairly cold and dry climate (Bonnefille and Riollet, 1988; Hessler et al., 2010) and at Lake Masoko, Tanzania, where warm temperate and mixed forests were formed due to a moderately wet climate. During the Last Glacial Maximum (LGM, 19 ka BP to $23 \mathrm{ka} \mathrm{BP}$, Mix et al., 1999), forests had developed at both locations, although grass vegetation was still widespread (Vincens et al., 2007; Hessler et al., 2010). Stager et al. (2011), however, suggested 
that the southward shift of ITCZ might not be the only cause of tropical aridity during the HE1 and that tropical Africa and Asian rainfall systems weakened during the same period.

In tropical South America, pollen records indicate contrasting vegetation changes between the northern and southern limits of the ITCZ (Hessler et al., 2010) during the HE1, e.g., at the Cariaco Basin site (equatorial northern South America), which had a more open vegetation due to dry climate conditions (González et al., 2008; González and Dupont, 2009), while the Lake Caçó region (equatorial South America) was occupied by a denser forest during the HE1 than during the LGM period due to moist climate conditions (Ledru et al., 2001; Dupont et al., 2009). In Indonesia an open grass-rich vegetation during the LGM was inferred from a marine pollen record (van der Kaars, 1991), although the Borneo rainforest was probably preserved and might have extended to the continental shelf of the South China Sea (Morley, 2000). At the terrestrial Rawa Danau site (West Java, Indonesia), the lowland forest and C3 plant cover increased and the grass cover decreased between $17 \mathrm{ka} \mathrm{BP}$ to 15.4 ka BP, indicating enhanced precipitation (van der Kaars et al., 2001; Turney et al., 2006).

Previous model studies suggested that the southward shift of the ITCZ occurred as a response to a slowdown of the AMOC during the HE1 (e.g., Stouffer et al., 2006; Mulitza et al., 2008; Kageyama et al., 2009; Bozbiyik et al., 2011). In these studies, the AMOC weakening was induced by perturbing the freshwater balance of the North Atlantic Ocean (e.g., Claussen et al., 2003; Köhler et al., 2005; Menviel et al., 2008; Kageyama et al., 2010; Woillez et al., 2013). Using an Earth System Model of Intermediate Complexity (EMIC, Claussen et al., 2002), which includes a dynamic vegetation component, it has been demonstrated that model results and pollen records in tropical Africa and northern South America are generally consistent (Kageyama et al., 2005; Tjallingii et al., 2008; Handiani et al., 2012). However, in many EMICs the atmospheric component is simplified, in particular with respect to the representation of the hydrological cycle. This calls for a modeling study that uses a more complex atmospheric component.

The tropical vegetation response to climate changes during the HE1 was studied by Handiani et al. (2012) using the University of Victoria Earth System-Climate Model (UVic ESCM, cf. Weaver et al., 2001). For the present study, we used a set of slightly different simulations with the UVic ESCM model to compare the results to those of the Community Climate System Model version 3 (CCSM3, Collins et al., 2006; Yeager et al., 2006). Previous model intercomparison studies regarding the climatic response to HE1 either focussed on atmospheric and oceanic variables only, not taking vegetation changes into account (Kageyama et al., 2013), or analyzed models with simplified atmospheric components (Kageyama et al., 2010). By contrast, our purpose was to compare the tropical vegetation response to climate changes during the HE1 as simulated by two global climate models that differ in the complexity of their atmospheric components.

The UVic ESCM is an EMIC with a rather simple atmospheric component, while the CCSM3 is a comprehensive climate model that contains a state-of-the art atmospheric general circulation model. Nevertheless, both models contain a dynamic global vegetation component (Meissner et al., 2003 and Levis et al., 2004, respectively), which are run with a similar resolution and allows comparing their results. In addition, the model results were compared to the available pollen records from tropical vegetation.

The comparison between model results and pollen records is not straightforward. Mostly, a dynamic global vegetation component represents the vegetation cover in terms of plant functional types (PFTs), while compilations of pollen records are available in terms of biome distributions (Prentice et al., 1996; Hessler et al., 2010). To directly compare models and pollen records, either the pollen records should be assigned to PFTs or the model results should be converted into biome distributions. In our study, the simulated vegetation covers were mapped onto biome distributions (Schurgers et al., 2006; Handiani et al., 2012), allowing for both a model intercomparison and a comparison of the simulated biogeographies with pollen-based reconstructions.

\section{Models and experimental design}

In the present study, we used the UVic ESCM version 2.8 (Weaver et al., 2001). The atmospheric component of this model contains a parameterization of anomalous nearsurface winds to take into account the dynamical wind feedback (Fanning and Weaver, 1997), which has not been used in the UVic simulations by Handiani et al. (2012). In this parameterization, wind field and wind stress anomalies are calculated from surface air temperature anomalies (Weaver et al., 2001). These wind field anomalies are then added to the prescribed mean wind field to account for the dynamic response of the atmosphere to sea surface temperature anomalies, which has a stabilizing effect on the AMOC (Fanning and Weaver, 1997). Furthermore, the dynamic vegetation model TRIFFID (Cox, 2001) is included in this version of the UVic ESCM to simulate the terrestrial biosphere in terms of soil carbon storage and five PFTs (Table 1). All components of the UVic ESCM share the same resolution of $3.6^{\circ}$ by $1.8^{\circ}$ (longitude $\times$ latitude) with one vertically averaged layer in the atmospheric model and nineteen levels in the ocean model.

In addition, we employed the low-resolution version of CCSM3 (Collins et al., 2006), which is described in detail by Yeager et al. (2006). In this version, the resolution of the atmospheric model is given by T31 spectral truncation (corresponding to a transform grid with a nominal resolution of $3.75^{\circ}$ ) and 26 levels, while the ocean model has a nominal resolution of $3^{\circ}$ (like the sea ice component) and 25 
Table 1. The original PFTs as simulated by the UVic ESCM and CCSM3 are combined into four main types of PFTs to simplify the model intercomparison (Bonan and Levis, 2006). The UVic ESCM classification also makes use of the lowest temperature criteria (e.g. Kaplan et al., 2003; Sitch et al., 2003).

\begin{tabular}{|c|c|c|c|c|c|}
\hline & PFT description & $\begin{array}{c}\text { Broadleaf } \\
\text { Evergreen } \\
\text { trees }\end{array}$ & $\begin{array}{c}\text { Needleleaf } \\
\text { Evergreen } \\
\text { trees }\end{array}$ & $\begin{array}{l}\text { Deciduous } \\
\text { trees }\end{array}$ & Grasses \\
\hline \multirow[t]{5}{*}{$\begin{array}{l}\text { UVic } \\
\text { ESCM }\end{array}$} & Broadleaf tree $(\mathrm{BL})$ & $\begin{array}{c}\mathrm{X} \\
\mathrm{IF} \mathrm{Tc}_{\min } \\
\geq 15.5^{\circ} \mathrm{C}\end{array}$ & & $\begin{array}{c}\mathrm{X} \\
\mathrm{IF} \mathrm{Tc} \text { min } \\
<15.5^{\circ} \mathrm{C}\end{array}$ & \\
\hline & Needleleaf tree (NL) & & 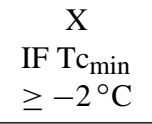 & 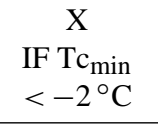 & \\
\hline & $\mathrm{C}_{3}$ grass $(\mathrm{C} 3)$ & & & & $\mathrm{X}$ \\
\hline & $\mathrm{C}_{4}$ grass $(\mathrm{C} 4)$ & & & & $\mathrm{x}$ \\
\hline & Shrubs (SH) & & & & $\mathrm{X}$ \\
\hline \multirow[t]{10}{*}{ CCSM3 } & Tropical broadleaf evergreen tree & $\mathrm{X}$ & & & \\
\hline & Tropical broadleaf deciduous tree & & & $\mathrm{X}$ & \\
\hline & Temperate broadleaf evergreen tree & $\mathrm{X}$ & & & \\
\hline & Temperate needleleaf evergreen tree & & $\mathrm{X}$ & & \\
\hline & Temperate broadleaf deciduous tree & & & $\mathrm{X}$ & \\
\hline & Boreal needleleaf evergreen tree & & $\mathrm{X}$ & & \\
\hline & Boreal deciduous & & & $\mathrm{X}$ & \\
\hline & $\mathrm{C} 4$ grass & & & & $\mathrm{X}$ \\
\hline & $\mathrm{C} 3$ grass & & & & $\mathrm{X}$ \\
\hline & C3 Arctic grass & & & & $\mathrm{X}$ \\
\hline
\end{tabular}

levels. The latitudinal resolution of the ocean grid is variable, with finer resolution around the equator (up to $0.9^{\circ}$ ). The dynamic global vegetation model (DGVM; Levis et al., 2004) is based on the Lund-Potsdam-Jena (LPJ) model (Sitch et al., 2003; Bonan and Levis, 2006). It is coupled to the Community Land Model version 3 (CLM3; Oleson et al., 2004), and thus we refer to it as the CLM-DGVM. CLM-DGVM has the same horizontal resolution as the atmosphere. In order to improve the simulation of the land surface hydrology, which affects the biogeography of vegetation, we implemented new parameterizations for canopy interception and soil evaporation into the CLM-DGVM following Oleson et al. (2008). The model simulates ten PFTs, which differ in their physiological, morphological, phenological, bioclimatic and fireresponse attributes. Seven PFTs refer to trees and three PFTs to non-tree vegetation cover (Table 1).

We performed two sets of experiments with each model. Each set of experiments was meant to simulate the vegetation distribution characteristics of the background climate of the LGM and HE1. The boundary conditions of the LGM and HE1 climates were similar in both models; for example, the
$\mathrm{CO}_{2}$ concentration was set to $185 \mathrm{ppm}$ and the continental ice sheet topography was based on the ICE-5G dataset for the LGM (Peltier, 2004). The details of the experimental design are summarized below:

i. The LGM simulation with the UVic ESCM (LGM_UVic) was similar to the LGM simulation by Handiani et al. (2012), except for the different parameterization of anomalous near-surface winds. The LGM simulation with the CCSM3 (LGM_CCSM) was similar to the CCSM3 LGM simulation by Merkel et al. (2010), except that the DGVM was activated and the land surface hydrology was improved (see above). Both LGM simulations were integrated until equilibrium was reached, which was taken to be after $2000 \mathrm{yr}$ for the LGM_UVic and $1500 \mathrm{yr}$ for the LGM_CCSM simulation.

ii. The HE1 simulations were identical to the LGM simulations as described in (i), except that a freshwater flux anomaly was imposed on the North Atlantic Ocean, which was added in both models at the same constant 
rate of $0.2 \mathrm{~Sv}\left(1 \mathrm{~Sv}=10^{6} \mathrm{~m}^{3} \mathrm{~s}^{-1}\right)$ for the whole duration of the experiment (500 model years). The location of the freshwater flux anomaly differed in each model. Freshwater was added at the St. Lawrence River mouth in the HE1_UVic (Handiani et al., 2012), while it was distributed over the Greenland Iceland-Norwegian Seas (north of about $65^{\circ} \mathrm{N}$ ) in the HE1_CCSM simulation (Merkel et al., 2010).

The model analysis and discussion refer to model output time-averaged over the last $100 \mathrm{yr}$ of each simulation. As specified above, the two models simulate a different number of PFTs. Therefore, to facilitate model comparison, the PFT output of each model was classified into four generic types of PFTs, namely broadleaf evergreen trees, needleleaf evergreen trees, deciduous trees and grasses (see Table 1). The PFT cover and the surface temperature of each model were used to generate the biome distribution. Given the different numbers of simulated PFTs, a different scheme to estimate the biome distribution had to be used for each model. The scheme for the UVic ESCM (Table 2) is described by Handiani et al. (2012) and uses the fractional coverage of the five PFTs and the atmospheric temperature from the model output. The percentage of PFT coverage allowed evaluation of the dominant PFT in each grid cell of the model (Table 2a). The simulated atmospheric temperatures served to calculate the environmental constraints for the biomes, such as temperature of the coldest month (Tc), temperature of the warmest month (Tw), and the number of growing degree-days above $0^{\circ} \mathrm{C}$ and $5^{\circ} \mathrm{C}$ (GDD0 and GDD5, respectively, Table $2 \mathrm{~b}$ ). The biome scheme for the CCSM3 was adopted from a study by Schurgers et al. (2006), who applied it to the LPJ model output for the Eemian and the Holocene (Table 3). It was applied to the fractional coverage of the ten PFTs (Table 1) from the output of the CLM-DGVM model, together with the air surface temperature from the atmospheric model. In summary, (1) simplified PFTs were defined that allowed for a model intercomparison and a detection of shifts in vegetation cover in long-term model simulations and (2) biomes were derived from the UVic ESCM and the CCSM3 output that enabled a direct comparison to pollen records.

\section{Results}

\subsection{Climate changes}

The AMOC gradually decreased in both models in response to the freshwater perturbation, but in each model the degree of reduction was different (not shown). In the LGM_UVic simulation, the maximum of the AMOC stream function started from a maximum strength of $\sim 12 \mathrm{~Sv}$ and eventually collapsed after $100 \mathrm{yr}$ of simulation time, while in the LGM_CCSM simulation, it decreased from $14 \mathrm{~Sv}$ to $4 \mathrm{~Sv}$ (not shown). Moreover, the regional pattern and amplitude of the surface air temperature anomaly is very different between the
Table 2a. Distribution of dominant PFTs, which is based on the percentage of PFT coverage for the UVic ESCM results simulation.

\begin{tabular}{ll}
\hline Dominant PFTs or PFTs mixture & PFT coverage \\
\hline & $\mathrm{BL}, \mathrm{NL}, \mathrm{SH}, \mathrm{C}_{3}, \mathrm{C}_{4}$ over $50 \%$ \\
Broadleaf tree (BL) & $\mathrm{BL} \geq 50 \%$ \\
Needleleaf tree (NL) & $\mathrm{NL} \geq 50 \%$ \\
Shrubs $(\mathrm{SH})$ & $\mathrm{SH} \geq 50 \%$ \\
$\mathrm{C}_{3}$ grass $\left(\mathrm{C}_{3}\right)$ & $\mathrm{C}_{3} \geq 50 \%$ \\
$\mathrm{C}_{4}$ grass $\left(\mathrm{C}_{4}\right)$ & $\mathrm{C}_{4} \geq 50 \%$ \\
\hline & $\mathrm{BL}, \mathrm{NL}, \mathrm{SH}, \mathrm{C}_{3}, \mathrm{C}_{4}$ less than $50 \%$ \\
Mixed trees & $\mathrm{BL}+\mathrm{NL} \geq 50 \%$ \\
Mixed vegetation (without trees) & $\mathrm{SH}+\mathrm{C} 3+\mathrm{C}_{4} \geq 50 \%$ \\
Open vegetation & $20 \% \leq \mathrm{BL}+\mathrm{NL}+\mathrm{SH}+\mathrm{C}_{3}+\mathrm{C}_{4} \geq 50 \%$ \\
Barren soil & $\mathrm{BL}+\mathrm{NL}+\mathrm{SH}+\mathrm{C}_{3}+\mathrm{C}_{4}<20 \%$ \\
\hline
\end{tabular}

If the percentage is over $50 \%$, the PFT potential is set equal to the dominant PFT (broadleaf tree, needleleaf tree, shrubs, $\mathrm{C} 3$ grass, or $\mathrm{C} 4$ grass). If it is less than $50 \%$, the grid cell is designated as mixed trees if it is dominated by tree PFTs, as mixed vegetation if non-trees PFTs are dominant, as open vegetation if all PFTs are between $20 \%$ and $50 \%$ and as desert if all PFTs together are less than $20 \%$ (Crucifix et al., 2005).

two models (Fig. 1a and c). The negative surface temperature anomalies for HE1 were around $-2{ }^{\circ} \mathrm{C}$ for the UVic ESCM and around $-4{ }^{\circ} \mathrm{C}$ for the CCSM3 off northwest Africa. The positive temperature anomalies in the Southern Hemisphere were also larger in the CCSM3 than in the UVic ESCM. In the tropics, the climate simulated by the UVic ESCM was only slightly (between $0{ }^{\circ} \mathrm{C}$ to $1^{\circ} \mathrm{C}$ ) colder in the $\mathrm{HE} 1$ experiment compared to the LGM experiment, whereas in the CCSM3, the northern equatorial Atlantic Ocean was colder by up to $2^{\circ} \mathrm{C}$ (Fig. 1a and c). Both models thus simulated a collapse of the AMOC associated with a strong cooling in the Northern Hemisphere and a slight warming in the Southern Hemisphere. The cooling was most pronounced over the North Atlantic Ocean, and the corresponding surface air temperature anomaly was larger in the CCSM3. The lower surface temperatures in the Northern Hemisphere have also been recorded for the HE1 (Grootes et al., 1993), supporting the model results. Moreover, the larger temperature anomalies in the CCSM 3 of $2{ }^{\circ} \mathrm{C}$ to $3{ }^{\circ} \mathrm{C}$ (Fig. 1c) correspond better to the paleorecord of the subtropical North Atlantic than those in the UVic ESCM (between $0^{\circ} \mathrm{C}$ to $1^{\circ} \mathrm{C}$, Fig. 1a) (e.g. Niedermeyer et al., 2009). The simplified atmospheric component in the UVic ESCM is most likely responsible for the muted response in the surface air temperature.

The weakening of the AMOC and an asymmetric surface temperature response between the two hemispheres were responsible for a southward shift of the tropical rain belt as suggested by the simulated precipitation patterns (Fig. $1 b$ and $d$ ). The pattern in the UVic ESCM was of rather large scale and extended beyond the ITCZ region. In the tropical Atlantic region, the precipitation differences between the HE1_UVic and the LGM_UVic simulation were around $-0.25 \mathrm{~mm} \mathrm{day}^{-1}$ north of the equator and $0.5 \mathrm{~mm} \mathrm{day}^{-1}$ south of the equator (Fig. 1b). In the CCSM3, the precipitation differences between the HE1 and the LGM 
Table 2b. The combination of environmental constraints and potential PFTs are used to compute the biome distribution from UVic ESCM results (Handiani et al., 2012).

\begin{tabular}{|c|c|c|c|c|c|c|}
\hline \multirow{3}{*}{$\begin{array}{l}\text { Dominant PFTs } \\
\text { or PFTs mixture }\end{array}$} & \multicolumn{5}{|c|}{ Environmental Constraints } & \multirow[b]{3}{*}{ Mega biomes } \\
\hline & \multirow{2}{*}{$\begin{array}{r}\mathrm{Tc} \min \\
\left({ }^{\circ} \mathrm{C}\right)\end{array}$} & \multirow{2}{*}{$\begin{array}{r}\text { GDD5 } \\
\min \end{array}$} & \multirow{2}{*}{$\begin{array}{r}\text { GDD0 } \\
\text { min }\end{array}$} & \multicolumn{2}{|c|}{$\mathrm{Tw}\left({ }^{\circ} \mathrm{C}\right)$} & \\
\hline & & & & $\min$ & $\max$ & \\
\hline BL tree & 15.5 & & & & & Tropical forest \\
\hline BL tree or mixed trees & 5 & & & & & Warm temperate forest \\
\hline BL tree or NL tree or mixed trees & -2 & & & & & Temperate forest \\
\hline $\mathrm{BL}$ tree or NL tree or mixed trees & -32.5 & & & & & Boreal forest \\
\hline $\begin{array}{l}\text { Grass }\left(C_{3}, C_{4}\right) \text { or mixed } \\
\text { vegetation or open vegetation }\end{array}$ & 17 & & & & & Savannah and dry woodland \\
\hline $\begin{array}{l}\text { Grass }\left(C_{3}, C_{4}\right) \text { or mixed } \\
\text { vegetation or open vegetation }\end{array}$ & & 500 & & 10 & & Grassland and dry shrubland \\
\hline Barren soil & & & & 22 & & Desert \\
\hline SH or mixed vegetation & & & & & 15 & Dry tundra \\
\hline SH or mixed vegetation & & & 800 & & 15 & Tundra \\
\hline
\end{tabular}

The environmental constraints were chosen based on the definition of biomes in the BIOME 4 model (Kaplan et al., 2003).

simulation were around $-2.5 \mathrm{~mm} \mathrm{day}^{-1}$ north of the equator and $2.0 \mathrm{~mm} \mathrm{day}{ }^{-1}$ south of the equator (Fig. 1c). The precipitation differences for CCSM3 were much larger between $10^{\circ} \mathrm{S}$ and $10^{\circ} \mathrm{N}$ in the tropics than in the other regions. The anomalies of the zonally averaged precipitation in CCSM3 showed a drying north of the equator by up to $0.8 \mathrm{~mm} \mathrm{day}^{-1}$ and a wetting south of the equator by a similar amount, thus sharply reflecting the southward shift of the rain belt (Fig. 1e). A comparison of the magnitude of precipitation anomalies in the HE1_UVic and the HE1_CCSM simulations revealed that the minimum and maximum anomalies in the HE1_UVic simulation were clearly weaker (min. $-0.86 \mathrm{~mm} \mathrm{day}^{-1}$ and max. of $0.48 \mathrm{~mm} \mathrm{day}^{-1}$ ) compared to the HE1_CCSM simulation (min. of $-4.19 \mathrm{~mm} \mathrm{day}^{-1}$ and max. of $2.80 \mathrm{~mm} \mathrm{day}^{-1}$ ).

Tropical hydrological records of the HE1 show a differentiated picture. South American records from around 16$17 \mathrm{ka} \mathrm{BP}$ registered a southward shift of the tropical rain belt. In contrast to the record from the Cariaco Basin, which indicates aridity, records farther south in the tropical Andes and in Amazonia suggest an increase of precipitation during the same period (Peterson et al., 2000; Wang et al., 2004; Denton et al., 2010). This precipitation pattern during the HE1 in tropical South America was better reproduced in the CCSM3 simulation (Fig. 1d) than in the UVic ESCM (Fig. 1b).

Both model simulations suggested a drier climate in equatorial West Africa, which is supported by records from, e.g., Lake Bosumtwi, Lake Barombi Mbo-Cameroon and the Gulf of Guinea (e.g., Stager et al., 2011; Hessler et al., 2010). For the southern parts of equatorial western Africa, both models simulated a wetter climate, which is consistent with proxy records from further south offshore Namibia (MD962094) (e.g., Stager et al., 2011). However, precipitation patterns for eastern Africa differed in both models. The UVic ESCM showed a mostly dry climate (Fig. 1b), while the CCSM3 indicated a dry climate in equatorial northeastern Africa and a wet climate in tropical southeastern Africa (Fig. 1d). The latter result is compatible with a southward displacement of the rain belt during the HE1, in line with a number of hydroclimatic reconstructions from eastern Africa (Schefuß et al., 2011; Thomas et al., 2012).

\subsection{The vegetation cover response}

In this section, we will discuss changes in vegetation cover in terms of the simplified PFTs as defined in Table 1 (see also Sect. 2), which allows for a direct comparison between the output from the UVic ESCM and the CCSM3. Our results showed that the southward shift of the tropical rain belt triggered vegetation changes in the tropics, with spatially varying degree and dominance. In the HE1 experiment of both models, broadleaf evergreen tree cover decreased in tropical northern Africa, but varied in South America (Fig. 2a and b). In the UVic ESCM, it was reduced by $60 \%$ in the Sahel region and southeast Brazil and it was also reduced in equatorial western South America by around $20 \%$ to $40 \%$ (Fig. 2a). In case of the CCSM3, broad-leaved tree cover decreased by up to $40 \%$ in West Africa and by 30 to $40 \%$ in southeast Brazil, but increased in equatorial western South America by ca. $40 \%$ (Fig. 2b). Furthermore, the decrease in broadleaf evergreen tree cover in Southeast Asia was less than $10 \%$ in the UVic ESCM but around $20 \%$ in the CCSM3 (Fig. 2a and b).

The change in needleleaf evergreen tree cover was relatively small in the tropics in both HE1 experiments (Fig. 2c and d). Similar to present-day climate, the needleleaf evergreen trees dominate at high latitudes, while in the tropics, they usually occur only at higher altitudes. The deciduous tree cover was reduced by more than $60 \%$ in the eastern 
(a)

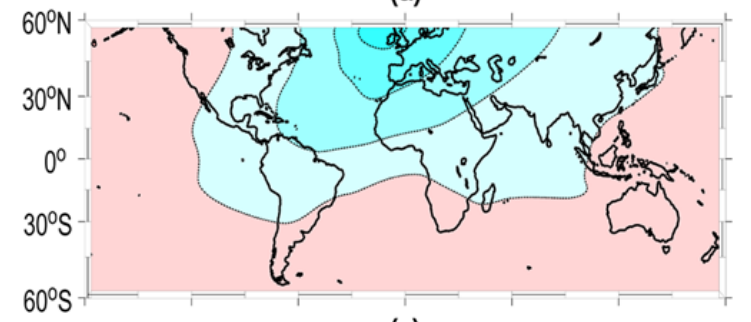

(c)

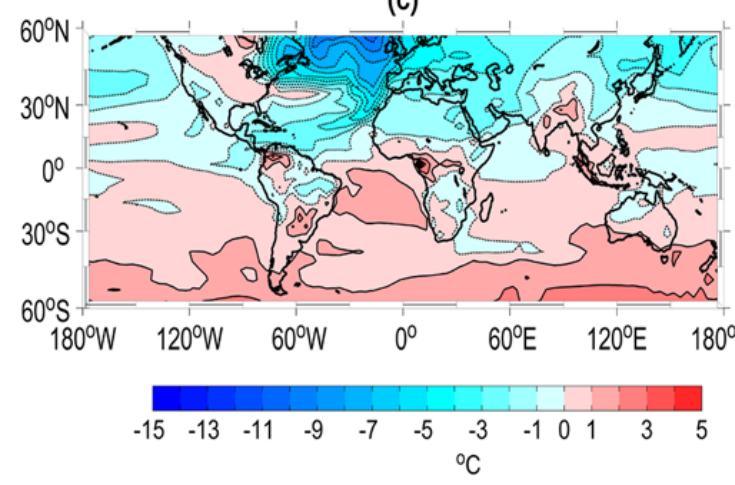

(b)

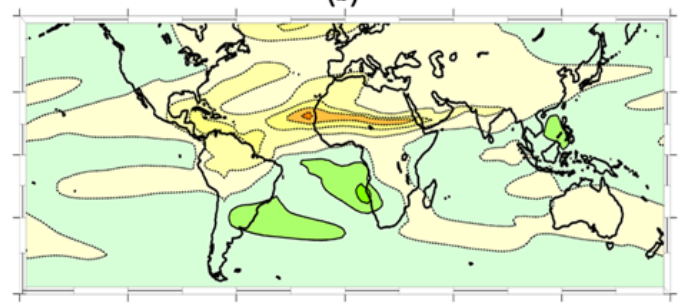

(d)

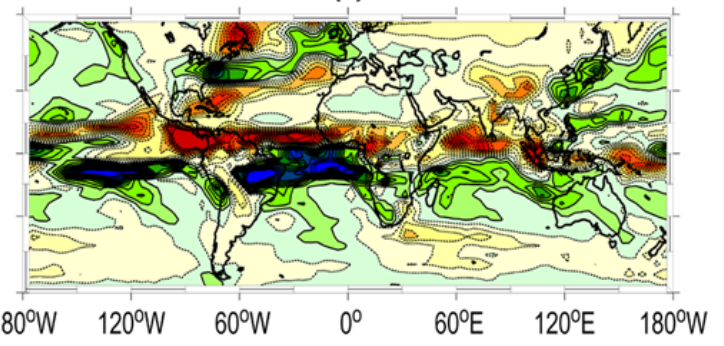

$\begin{array}{ccccccccccc}-2.0 & -1.6 & -1.2 & -0.8 & -0.4 & 0.0 & 0.4 & 0.6 & 1.2 & 1.6 & 2.0 \\ \mathrm{~mm} / \text { day } & & & & \end{array}$

(f)

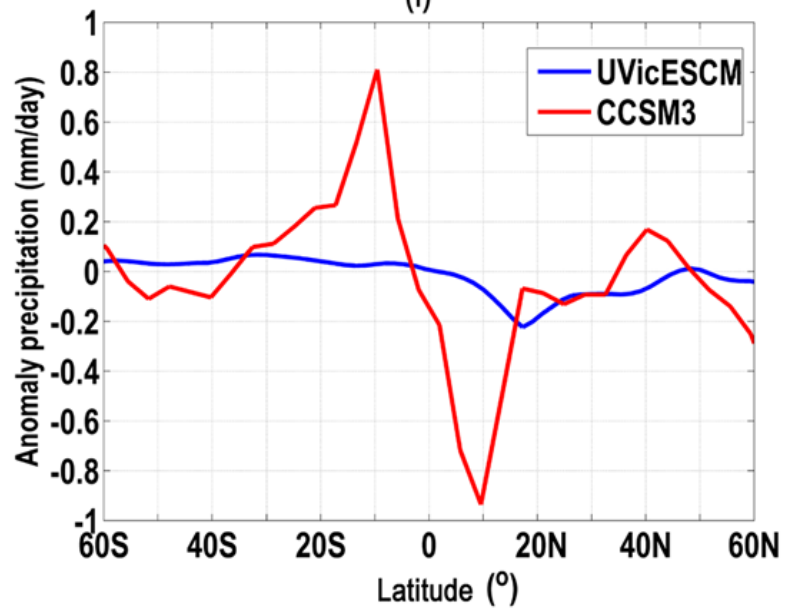

Fig. 1. Annual mean anomalies of surface temperature (a and $\mathbf{c}$ ) and precipitation (b and d) between HE1_UVic and LGM_UVic (top) and between HE1_CCSM and LGM_CCSM (middle) simulations. The contour intervals are fixed at $1^{\circ} \mathrm{C}$ for surface temperature and $0.5 \mathrm{~mm}$ day ${ }^{-1}$ for precipitation. (e) The global zonally averaged precipitation differences between HE1 and LGM simulations for the UVic ESCM (blue) and the CCSM3 model (red).

Sahel region in the UVic ESCM. By a similar percentage deciduous tree cover decreased in equatorial western South America, the central African region and Southeast Asia in the CCSM3 (Fig. 2e and f). Meanwhile, the deciduous tree cover in central Brazil increased by around $60 \%$ in both models, although these changes were larger in the CCSM3 than in the UVic ESCM. This is probably the effect of differences in model hydrology; precipitation increased by more than $1.6 \mathrm{~mm} \mathrm{day}^{-1}$ (Fig. 1d) in the CCSM3, while the increase is minor in the UVic ESCM (Fig. 1b). In tropical northern Africa (i.e., the Sahel region), the grass cover increased by around $60 \%$ in both models. However, the UVic ESCM simulated the grass cover further north and over a wider longitudinal range than the CCSM3. In tropical South America, the grass cover was relatively unchanged in the UVic ESCM simulation, while it mostly decreased in the CCSM3 simulation (Fig. $2 \mathrm{~g}$ and $\mathrm{h}$ ). The grass cover change was more pronounced in the CCSM3 simulation than in the UVic ESCM simulation, e.g., it was reduced in tropical North America and South America, while it increased by $20 \%$ to $40 \%$ in northwest South America and tropical Africa and by about $60 \%$ in Southeast Asia (Fig. 2h). It was reduced by $20 \%$ to $80 \%$ in tropical western Africa, while it increased by up to $80 \%$ in tropical central and eastern Africa in the UVic ESCM (Fig. 2g). 
Broadleaf evergreen trees
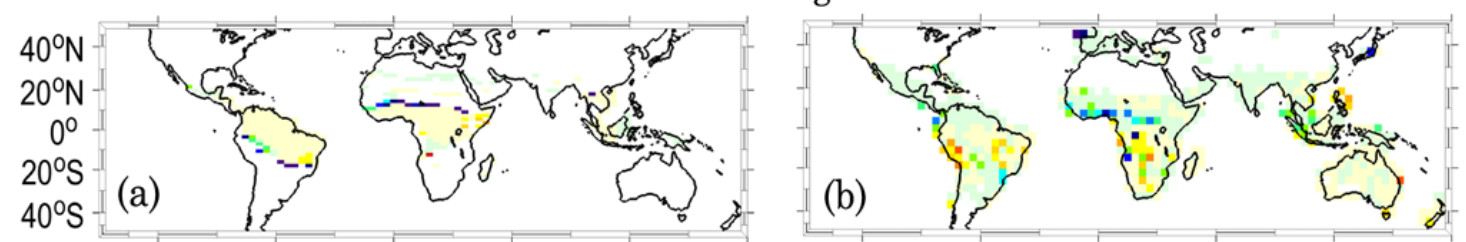

Needleleaf evergreen trees
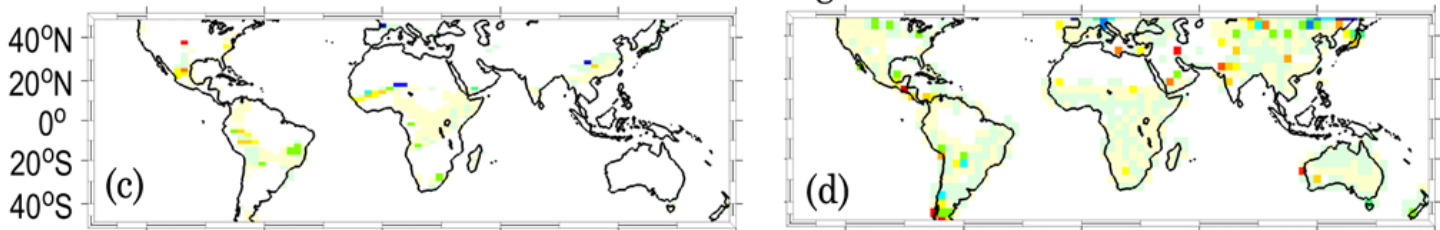

Deciduous trees
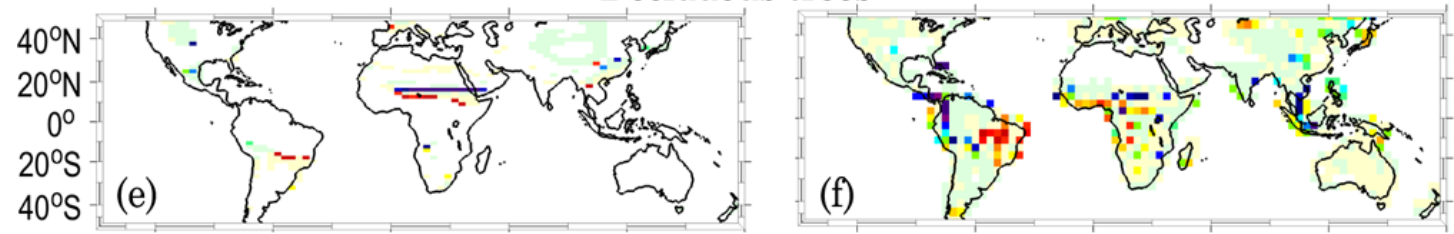

\section{Grasses}

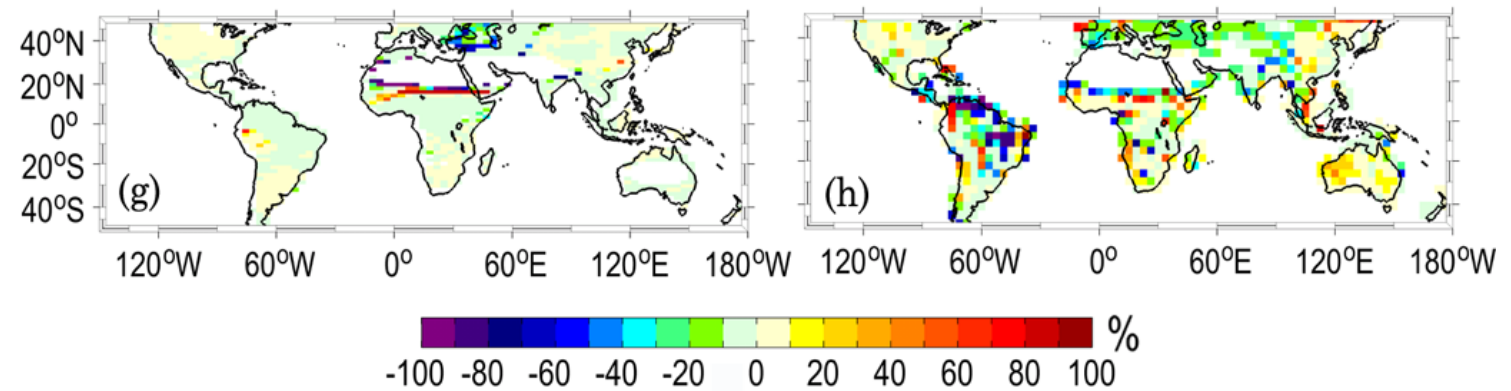

Fig. 2. Annual mean differences of PFT cover between HE1 and LGM simulations for the UVic ESCM (left panels) and the CCSM3 (right panels). The classification into the four PFTs is defined in Table 1.

The changes of tropical vegetation cover during the HE1 simulations have been analyzed using the zonally averaged tree and grass covers from both models. The annual mean anomalies of zonally averaged tree and grass covers between the HE1 and the LGM experiments are shown for three tropical regions: South America (Fig. 3a and b), Africa (Fig. 3c and d) and Southeast Asia (Fig. 3e and f). The tree cover in the UVic ESCM was reduced by $60 \%$ in tropical Africa around $15^{\circ} \mathrm{N}$, while the grass cover increased by a similar percentage at the same latitude (Fig. 3c). A similar pattern also emerged from the CCSM3 simulation, where at around $10^{\circ} \mathrm{N}$ the tree cover decreased by $20 \%$ while the grass cover increased by a comparable percentage (Fig. 3d). Moreover, in tropical South America, the tree and the grass cover in the CCSM3 simulation were reduced by about $30-50 \%$ between $5^{\circ} \mathrm{N}-10^{\circ} \mathrm{N}$, while an opposite change of tree and grass cover by about $10-30 \%$ occurred around $10^{\circ} \mathrm{S}$ (Fig. 3b). The UVic ESCM did not show any pronounced changes in tropical Southeast Asia (Fig. 3e), while the CCSM3 tree cover generally decreased and the grass cover increased in that region (Fig. 3f). In some of the locations mentioned above, e.g., in tropical northern Africa, the vegetation changes from tree to grass cover in the HE1 simulations, which are interpreted as the vegetation response to aridification during the HE1. On the other hand, a wetter climate in southern equatorial South America resulted in trees gaining over grasses (Fig. 3b). The tree and grass cover south of the equator in the UVic ESCM (Fig. 3a, c and e), however, changed by less than $5 \%$, whereas the differences in CCSM3 (Fig. 3b, $\mathrm{d}$ and f) were larger than $10 \%$.

\subsection{Biome distribution comparison}

The PFTs output from both models were converted into biome distributions, and in this section we compare the biome distributions to pollen records. For this comparison, we used pollen records for the LGM and the HE1 periods from tropical South America and Africa (Fig. 4a and b), 
Table 3. The biome distribution estimation scheme adopted from a study by Schurgers et al. (2006) applied to the CCSM3 output. The temperature limitation is based on bioclimatic parameters for survival and establishment of PFTs in the CCSM3 (Bonan et al., 2003).

\begin{tabular}{|c|c|c|c|c|}
\hline \multicolumn{3}{|c|}{ PFT fraction $(\%)$} & $\begin{array}{l}\text { Temperature } \\
\text { limitation }\left({ }^{\circ} \mathrm{C}\right)\end{array}$ & $\begin{array}{l}\text { Mega biomes and } \\
\text { non-biomes description }\end{array}$ \\
\hline \multirow[t]{7}{*}{$C_{\mathrm{v}}>20$} & \multirow[t]{4}{*}{$C_{\mathrm{f}}>80$} & $C_{\mathrm{f}, \text { trop }}>C_{\mathrm{f}, \text { temp }} ; C_{\mathrm{f}, \text { trop }}>C_{\mathrm{f}, \text { bor }}$ & & Tropical forest \\
\hline & & \multirow[t]{2}{*}{$C_{\mathrm{f}, \text { temp }}>C_{\mathrm{f}, \text { trop }} ; C_{\mathrm{f}, \text { temp }} \geq C_{\mathrm{f}, \text { bor }}$} & $3.0<T_{c}<18.8$ & Warm temperate forest \\
\hline & & & & Temperate forest \\
\hline & & $C_{\mathrm{f}, \text { bor }}>C_{\mathrm{f} \text {,trop }} ; C_{\mathrm{f}, \text { bor }} \geq C_{\mathrm{f}, \text { temp }}$ & & Boreal forest \\
\hline & \multirow[t]{3}{*}{$C_{\mathrm{f}}<=80$} & $C_{\mathrm{v}, \mathrm{C}_{4}} \geq C_{\mathrm{v}, \mathrm{C}_{3}}$ & & Savannah and dry woodland \\
\hline & & $C_{\mathrm{v}, \mathrm{C}_{3}} \geq C_{\mathrm{v}, \mathrm{C}_{4}}$ & $T_{c}>-17.0$ & Grassland and shrubland \\
\hline & & & $T_{c} \leq-17.0$ & Tundra/Dry tundra \\
\hline \multirow[t]{3}{*}{$C_{\mathrm{V}}<=20$} & & & $T_{c}>0.0$ & Desert \\
\hline & & & $T_{c}<0.0$ & Ice \\
\hline & & & & Barren \\
\hline
\end{tabular}

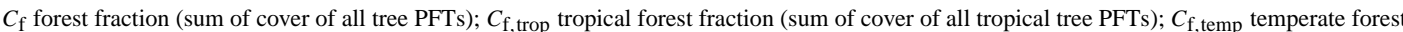
fraction; $C_{\mathrm{f} \text {, bor }}$ boreal forest fraction; $C_{\mathrm{v}}$ vegetation fraction (sum of cover of all PFTs); $T_{C}$ air surface temperature; $C_{\mathrm{v}, \mathrm{C}_{3}} \mathrm{C}_{3}$ grasses fraction; $C_{\mathrm{v}, \mathrm{C}_{4}} \mathrm{C}_{4}$ grasses fraction.

which have been compiled by Hessler et al. (2010). Ten locations of high-resolution pollen records were selected, which cover the period of HE1 (Fig. 4b). The pollen records suggest that the LGM biomes are dominated by savannah in tropical South America and western tropical Africa, while in eastern tropical Africa biome distributions varied between tropical forest and grassland/shrubland (Fig. 4a). During the HE1 mainly the savannah biome occurred in the region around the tropical Atlantic Ocean, except in those locations where the forests biome became dominant, thereby replacing the LGM savannah, e.g., in Lake Caçó-northeast Brazil (record number 7, Fig. 4a and b).

Different characteristics in vegetation cover between the two models were shown in biome distributions derived from model outputs of the LGM and HE1 simulations (Fig. 5ad). Here, we illustrate biome distribution differences between the HE1 and the LGM simulation by highlighting those cells in which the HE1 biome differed from that of the LGM (Fig. 5e and f). In the LGM_UVic simulation the tropics were mainly covered by tropical forest (Fig. 5a). This changed in the HE1_UVic simulation of tropical northern Africa, where warm temperate forest replaced the tropical forest, and grassland replaced the warm temperate forest (Fig. 5e). In the CCSM3 simulation, the LGM was characterized by a relatively high proportion of the savannah biome in tropical South America and mixed biomes of tropical forest and savannah in tropical Africa (Fig. 5b). In the HE1_CCSM simulation (Fig. 5d), biomes changed in tropical northern Africa where grasslands were replaced by a desert expansion. Moreover, tropical forest replaced the savannah in central Brazil. On the other hand, in northern South America, the desert extended in the HE1_CCSM simulation compared to the LGM_CCSM (Fig. 5f). The biome pattern in the CCSM3 followed the southward shift of the tropical rain belt during the HE1, which caused a dry climate in northern South America and a wet climate in southern equatorial South America (Fig. 2d).

A comparison is presented to show where model results (Fig. 5c and d) are consistent with proxy information during the period of HE1 (Fig. 4b). The changes in tropical African forest as found in the HE1_UVic and the HE1_CCSM simulations mostly agreed with the pollen reconstruction (Fig. 5c and $\mathrm{d}$ ). According to both models and the pollen records, equatorial western Africa was covered by tropical forest corresponding to a wet climate. In southwest Africa, the pollen records indicated a warm temperate forest and farther south savannah (Fig. 4b). The HE1_UVic simulation agreed with both records in southwest Africa, while the HE1_CCSM simulation only agreed with one record (Fig. 5c and d) because the HE1_CCSM predicted savannah due to a relatively warm climate in these locations (Fig. 5d). Another discrepancy between the HE1_CCSM simulation and the pollen records is found in eastern Africa, where the model predicted tropical forest and grassland, while the records suggest warm-temperate forest and savannah (Fig. 4b).

The biome distributions derived from the model and pollen results were in disagreement at the Colônia site (Brazil). According to the pollen record, this region was covered by savannah, indicating a warm and dry climate (Fig. 4b). The tropical forest in the HE1_UVic and the HE1_CCSM simulations was broadly consistent with the pollen records of Lake Caçó (northeast Brazil). The HE1_CCSM simulation 


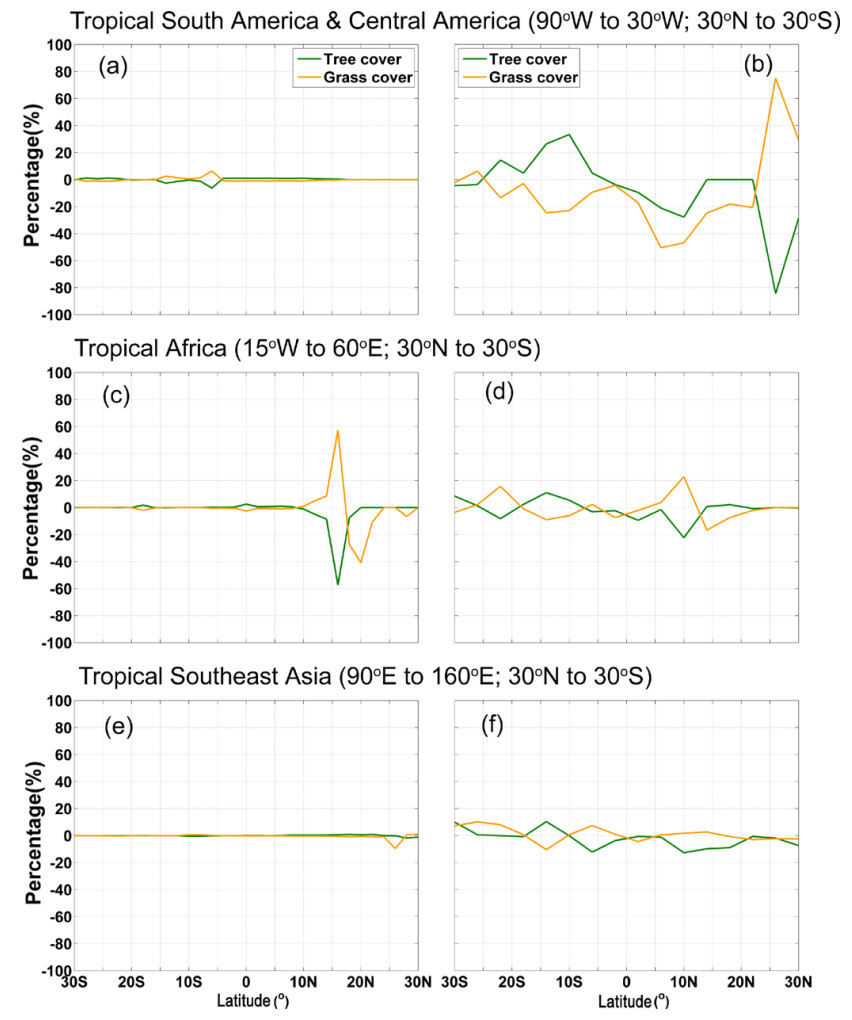

Fig. 3. Annual mean anomalies of regional zonally averaged tree and grass cover between HE1 and LGM for the UVic ESCM (left panels) and the CCSM3 (right panels). The regional areas are tropical South America and Central America (top), tropical Africa (middle) and tropical Southeast Asia (bottom).

(Fig. 5d) was also in agreement with the pollen record of core GeoB 3910-2 off the coast of northeast Brazil (site number 10 in Fig. 4b); both model and data indicated savannah. In contrast, for the same region, the HE1_UVic simulation predicted tropical forest (Fig. 5c).

A tropical Asian biome reconstruction for HE1 is not available yet; hence it is difficult to perform a thorough model-data comparison. However, the simulation of a savannah corridor in Sundaland in CCSM3 is worth noting as the existence of such a feature during the last glaciation is highly debated (e.g. Bird et al., 2005). From a modeling perspective, the changes in the biome distributions between the HE1 and LGM simulations were insignificant (Fig. 5e-f and PFT cover anomalies in Fig. 2), although some changes did occur in the CCSM3 model. For example, grass cover increased in southeast China and replaced savannah in the HE1_CCSM simulation (Fig. 5d).

\section{Discussion}

The simulations in the UVic ESCM presented here are different from Handiani et al. (2012). Both studies used the UVic ESCM and an identical experimental design, but Handiani et al. (2012) did not include the dynamical wind feedback parameterization. Regarding the precipitation patterns in the tropics, there are a few differences between the earlier study by Handiani et al. (2012) and our present study. Our preindustrial simulation (not shown) resulted in a climate that was warmer and drier than in the study by Handiani et al. (2012), most notably in southern equatorial South America and Africa as well as the Sahel region. Nevertheless, the HE1 simulations of both studies suggested similar tropical precipitation anomalies. Thus including the dynamical wind feedback parameterization in the UVic ESCM improved the representation of the precipitation pattern in the ITCZ region in the preindustrial simulation (not shown), but it only had a slight impact on the tropical precipitation response in the HE1 simulation. Moreover, despite the additional moisture transport by advection in this version of the UVic ESCM, the precipitation in the terrestrial tropics and the ITCZ region was still weaker when compared to the CCSM3. Weaver et al. (2001), who introduced the moisture transport by advection in the UVic ESCM, identified additional regions such as the mid-latitude North Atlantic Ocean and Pacific Ocean regions that need further improvement. The use of the dynamical wind feedback parameterization in the atmospheric component of the UVic ESCM barely influenced the tropical vegetation cover distribution in the preindustrial simulation (not shown). The smooth precipitation distribution from both preindustrial simulations led to a similarly smooth vegetation distribution in the tropics. For example, tree cover penetrated into the subtropics of northern and southern Africa (not shown, see Handiani et al., 2012).

The slowdown of the AMOC during the HE1 simulation caused an adjustment of the surface temperature called the "bipolar seesaw", which is characterized by a cooling in the Northern Hemisphere and a slight warming in the Southern Hemisphere (Broecker et al., 1985). In the tropics, the bipolar seesaw in turn influenced the precipitation patterns through feedbacks between ocean and atmosphere. Differences in the response of the surface air temperature of the North Atlantic region between both models could be related to the interaction with AMOC changes. When freshwater was imposed in the North Atlantic, the density pattern was changed followed by the occurrence of the thermal bipolar seesaw, which is based on variations of interhemispheric heat transport by the AMOC. Later the North Atlantic cooling strengthened the trade winds, which cooled the tropical SST through enhanced evaporation in the tropics, causing southward movement of the meridional SST gradient as well as the tropical rain belt. In case of the UVic ESCM, the mechanism also occurred, but the response was curbed, because the UVic ESCM contains a simplified atmospheric component with little capability of positive feedbacks and a much more diffusive heat transport. As the atmosphere in the UVic ESCM is represented by only one layer, the advective transport of moisture is vertically averaged and thus there is no vertical circulation or convection occurred; this necessarily affected the precipitation pattern in 


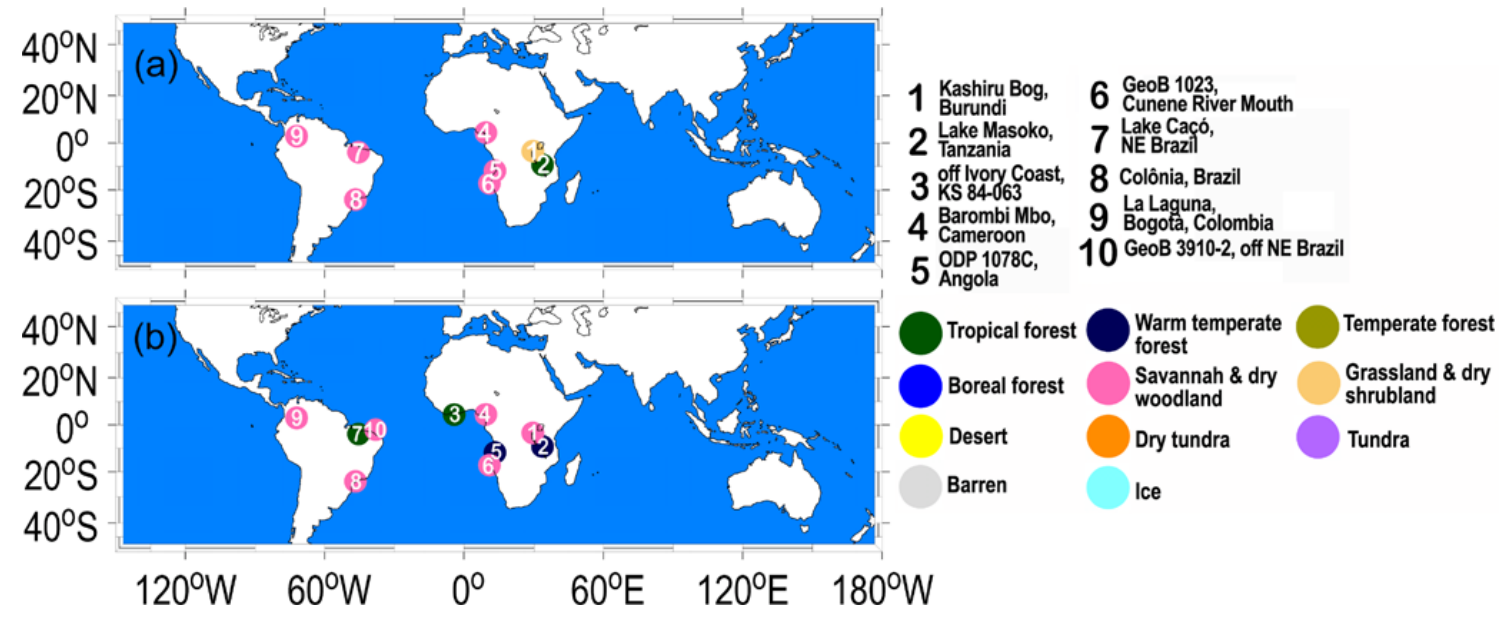

Fig. 4. Sites of pollen records compiled by Hessler et al. (2010) for the LGM (a) and HE1 (b). Biome reconstructions at each site are represented by the colors of the circles (see legend).
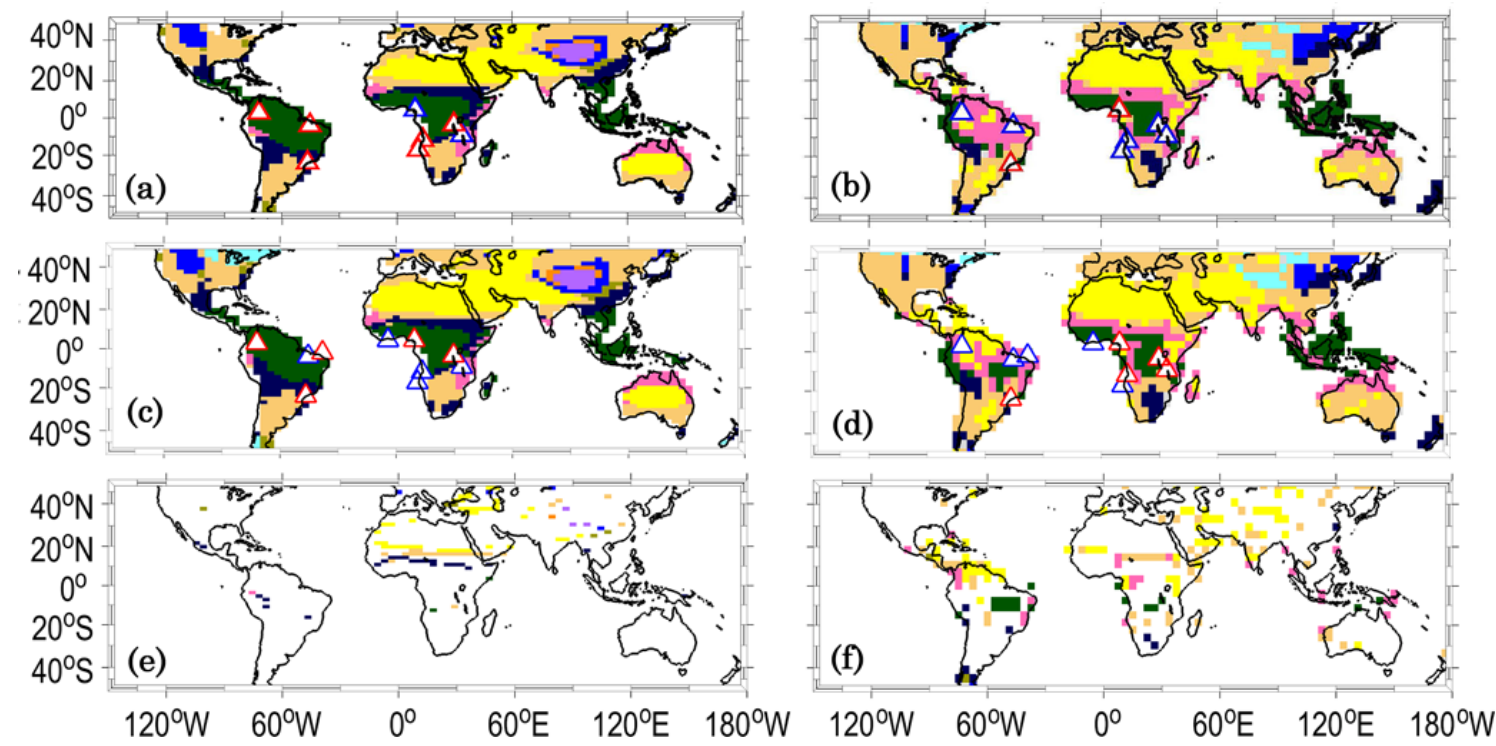

Fig. 5. The biome distributions computed from the simulations of LGM_UVic (a), LGM_CCSM (b), HE1_UVic (c) and HE1_CCSM (d). A comparison between model output and biome reconstruction of each location for the period of LGM and HE1 is indicated by whiteblue triangles where biomes computed from the model are similar to the reconstruction; white-red triangles denote where modelled and reconstructed biomes differ. Anomalies of biome distribution between the HE1 and LGM simulations of the UVic ESCM (e) and the CCSM3 (f). The anomaly shows the HE1 biome (from the HE1_UVic and the HE1_CCSM simulations) only in those grid cells that differ from the LGM simulations LGM_UVic and LGM_CCSM, respectively. See Fig. 4 for biome distribution legend.

the model, most distinctly around the tropical rain belt. Earlier studies with the UVic ESCM by Kageyama et al. (2010) and Handiani et al. (2012) also showed similar deficiencies. The CCSM3, which includes a comprehensive dynamic atmospheric component, showed a strong feedback between ocean and atmosphere, leading to a far greater response to changes in AMOC strength.

Our results demonstrated that positive precipitation anomalies developed over the equatorial South Atlantic Ocean and surrounding regions, while negative anomalies appeared over the tropical North Atlantic Ocean. In the CCSM3, the positive anomaly spanned an entire band south of the equator from central Brazil to central Africa with the maximum of this band over eastern Brazil. The negative anomalies ranged from the Sahel to Central America. These anomalies also occurred in the UVic ESCM, although much less pronounced as compared to the CCSM3. In the UVic ESCM, the highest positive anomalies extended farther into southeast South America and western Angola, while maximum negative anomalies were found in the Sahel region. 
Pronounced changes in broadleaf tree cover in the tropics were confined to the Sahel region, equatorial southern South America and western Africa. It seems that these regions were most sensitive to tropical climate changes due to HE1-like climate conditions. In the UVic ESCM in particular, changes in tree cover occurred mostly at the forests margins. Changes in tree cover were related to changes in grass cover. We indeed expected a shift from tropical trees to grass cover due to a drier climate in the Sahel region and a shift from grass cover to tree cover due to a wetter climate in southern equatorial South America. This was confirmed by the HE1_CCSM results around $10^{\circ} \mathrm{S}$ in tropical South America and around $10^{\circ} \mathrm{N}$ in tropical Africa, where tree cover and grass cover changed by comparable magnitudes. Similarly, according to the HE1_UVic results around $15^{\circ} \mathrm{N}$ in tropical Africa, tree cover decreased considerably while grass cover increased. Such a pattern is also found in the HE1 experiments by Köhler et al. (2005) and Menviel et al. (2008), where the vegetation shifts occur in the latitudinal band between $5^{\circ} \mathrm{S}$ and $15^{\circ} \mathrm{N}$.

According to Bonan and Levis (2006), the tropical forest in South America under present climate conditions is less extensive in CCSM3 than in the observations. The complex interaction within the hydrological cycle (between soil moisture, vegetation, evaporation, transpiration and precipitation) in that region leads to a considerable decrease in precipitation and tree cover. As a consequence, the broadleaf tree cover in tropical South America under preindustrial climate conditions was smaller in the CCSM3 than in the UVic ESCM. Correspondingly, in the HE1_CCSM simulation, tropical South America was covered by more open vegetation (e.g., savannah and grassland) than in the HE1_UVic simulation. However, the biome distribution in the HE1_CCSM simulation proved to be in agreement with pollen sites in tropical South America, and in spite of the deficiency of the simulated modern hydrological cycle in tropical South America, the CCSM3 captured the vegetation change during HE1 quite well.

The tropical forest simulated by both models in Southeast Asia is supported by the study of pollen records by Morley (2000), who suggests that the Borneo tropical forest persisted and even extended onto the continental shelf of the South China Sea during the last glacial period. Nevertheless, CCSM3 also suggested the appearance of a savannah corridor in Sundaland (on the Sunda shelf) as it has first been proposed by Heaney (1991). Moreover, in the HE1_CCSM simulation, the vegetation cover in tropical Southeast Asia responded to abrupt climate change in the northern Atlantic Ocean with changes in tree and grass cover of around $20 \%$. These changes were significantly larger than in the HE1_UVic simulation, which were less than $10 \%$. The CCSM3 results can be considered as an indication of a teleconnection between North Atlantic Ocean climate and vegetation cover in tropical Southeast Asia (e.g., Zhou et al., 2007; Lee et al., 2011). However, a more extensive compilation of paleovegetation data from this region is needed to ease the comparison between model and data and to corroborate this finding.

Comparing model output and pollen records is not an easy task; one complication in our study is that the definitions of the PFTs are not exactly the same. This problem becomes apparent when comparing pollen reconstructions from specific geographic locations (e.g., a mountain or lake) with model results, which often cannot represent those locations in required detail. Since models are mostly formulated in terms of PFTs, but are checked for consistency against pollen records or the present-day vegetation distribution, either the PFTs from the model output have to be converted into a biome distribution, or the pollen record has to be converted into PFTs comparable to the modeled PFTs. Several model studies have tackled this problem by developing a scheme to compute biomes based on the PFTs from the model output (e.g., Crucifix et al., 2005; Roche et al., 2007; Schurgers et al., 2006; Handiani et al., 2012). The weakness of this approach is that the calculation depends on specific model output; hence a scheme for one model cannot be used directly for another model as is illustrated by our separate schemes for the UVic ESCM and the CCSM3. In contrast, a number of techniques have been developed to convert the biome distribution derived from satellite or observational data into PFTs (e.g., Meissner et al., 2003; Poulter et al., 2011). Unfortunately, these approaches can only be used for present-day model results, since a biome distribution derived from satellite data is only available for the present-day vegetation.

On the other hand, the conversion of pollen data into biomes is also not trivial. Here we relied on the paper of Hessler et al. (2010), who reviewed high-resolution pollen records from tropical regions at both sides of the Atlantic Ocean covering the HE1 period. High-resolution pollen records were not available for all regions and, in addition, the differences in the regional floras make a direct comparison of pollen records from different locations difficult. Therefore, Hessler et al. (2010) simplified the vegetation records in terms of mega-biomes after Harrison and Prentice (2003). To this end, the pollen taxa are assigned to PFTs, which were grouped into mega-biomes to describe the main vegetation changes for each record in a consistent way, although a certain loss of information has to be taken into account. Nevertheless, the conversion into biomes as a common denominator enables us to compare vegetation records and models.

\section{Conclusions}

This study compared two simulations of HE1 by two different earth system models. Both models simulated a slowdown of the AMOC in response to a freshwater perturbation in the North Atlantic Ocean. The associated bipolar seesaw in surface temperature influenced the tropical climate through a southward shift of the rain belt. However, the effect 
on precipitation was smaller in the UVic ESCM than in the CCSM3.

The shift of the tropical rain belt caused drier climate conditions in the northern equatorial region and wetter climate conditions in the southern equatorial region, which also influenced the tropical vegetation patterns, specifically in tropical Africa around $15^{\circ} \mathrm{N}$ in the UVic ESCM and $10^{\circ} \mathrm{N}$ in the CCSM3. In southern equatorial Africa, there was no visible response to the freshwater hosing in the UVic ESCM, while in the CCSM3 opposite tree and grass cover occurred around $15^{\circ} \mathrm{S}$. The tree and grass cover in the CCSM3 in tropical South America also suggested opposite changes south of the equator $\left(10^{\circ} \mathrm{S}\right)$, while north of the equator (between $5^{\circ} \mathrm{N}$ and $10^{\circ} \mathrm{N}$ ) both decreased due to a drier climate. In addition, tree cover decreased and grass cover increased between $15^{\circ} \mathrm{N}$ and $10^{\circ} \mathrm{S}$ in Southeast Asia during the HE1 experiment in CCSM3.

The direct comparison of the simulated biome distribution and pollen records allows an assessment of the modeldata agreement without relying on indirect reconstructions of precipitation and temperature distributions from pollen records. Nevertheless, comparing model and pollen records has its own uncertainties; one of them is to have a coherent classification of biome distribution for both model and pollen records. For our study, we applied two such biomisation schemes, specific to each model, which allowed for a comparison between the model results and the available pollen records.

Finally, the agreement with the reconstructed biome distribution during HE1 varied in each model. The best correspondence was found in southwestern and equatorial western Africa as well as in northeastern Brazil. The vegetation cover simulated by CCSM3 in tropical Southeast Asia opens up the possibility that abrupt climate change in the North Atlantic Ocean may have a large-scale, even global impact on the terrestrial biosphere.

Acknowledgements. This work was funded by the Deutsche Forschungsgemeinschaft (DFG) as part of the German contribution to the Integrated Ocean Drilling Program (SPP 527) "Abrupt Climate Change in the African Tropics (ACCAT)" and the DFG Research Center/Excellence Cluster "The Ocean in the Earth System". The CCSM3 climate model experiments were run on the SGI Altix Supercomputer of the "Norddeutscher Verbund für Hoch- und Höchstleistungsrechnen" (HLRN). The authors are grateful to the Climate Modelling Group at the University of Victoria for providing the UVic ESCM. Finally, we thank the anonymous reviewers for their helpful comments and the handling editor Christopher Brierley.

Edited by: C. Brierley

\section{References}

Behling, H., Arz, H. W., Pätzold, J., and Wefer, G.: Late Quaternary vegetational and climate dynamics in Northeastern Brazil, inferences from marine core GeoB 3104-1, Quaternary Sci. Rev., 19, 981-994, 2000.

Bird, M. I., Taylor, D., and Hunt, C.: Paleoenvironment of insular Southeast Asia during the last glacial period: a savanna corridor in Sundaland?, Quaternary Sci. Rev., 24, 2228-2242, 2005.

Bonan, G. B. and Levis, S.: Evaluating Aspects of the Community Land and Atmosphere Models (CLM3 and CAM3) Using a Dynamic Global Vegetation Model, J. Climate, 19, 2290-2301, 2006.

Bonan, G. B., Levis, S., Sitch, S., Vertenstein, M., and Oleson, K. W.: A dynamic global vegetation model for use with climate models: Concepts and description of simulated vegetation dynamics, Glob. Change Biol., 9, 1543-1566, 2003.

Bonnefille, R. and Riollet, G.: The Kashiru pollen sequence (Burundi), Palaeoclimatic implications for the last 40,000 yr. B.P. in tropical Africa, Quaternary Res., 30, 19-35, 1988.

Bozbiyik, A., Steinacher, M., Joos, F., Stocker, T. F., and Menviel, L.: Fingerprints of changes in the terrestrial carbon cycle in response to large reorganizations in ocean circulation, Clim. Past, 7, 319-338, doi:10.5194/cp-7-319-2011, 2011.

Broecker, W. S.: Massive iceberg discharges as triggers for global climate change, Nature, 372, 421-424, 1994.

Broecker, W. S., Peteet, D. M., and Rind, D.: Does the oceanatmosphere system have more than one stable mode of operation?, Nature, 315, 21-26, 1985.

Claussen, M., Mysak, L. A., Weaver, A. J., Crucifix, M., Fichefet, T., Loutre, M. F., Weber, S. L., Alcamo, J., Alexeev, V. A., Berger, A., Calov, R., Ganopolski, A., Goosse, H., Lohmann, G., Lunkeit, F., Mokhov, I., Petoukhov, V., Stone, P., and Wang, Z.: Earth system models of intermediate complexity: closing the gap in the spectrum of climate system models, Clim. Dynam., 18, 579-586, 2002.

Claussen, M., Ganopolski, A., Brovkin, V., Gerstengarbe, F.-W., and Werner P.: Simulated Global-Scale Response of the Climate System to Dansgaard-Oeschger and Heinrich events, Clim. Dynam., 21, 361-370, 2003.

Collins, W. D., Rasch, P. J., Boville, B. A., Hack, J. J., McCaa, J. R., Williamson, D. L., Briegleb, B. P., Bitz, C. M., Lin, S.-J., and Zhang, M.: The formulation and atmospheric simulation of the Community Atmosphere Model version 3 (CAM3), J. Climate, 19, 2144-2161, 2006.

Cox, P. M.: Description of the "TRIFFID" dynamic global vegetation model, Hadley Centre Technical Note 24. Met Office, Bracknell, 2001.

Crucifix, M., Betts, R. A., and Hewitt, C. D.: Pre-industrial potential and Last Glacial Maximum global vegetation simulated with a coupled climate-biosphere model: diagnosis of bioclimatic relationships, Global Planet. Change, 45, 295-312, 2005.

Denton, G. H., Anderson, R. F., Toggweiler, J. R., Edward, R. L., Schaefer, J. M., and Putnam, A. E.: The Last Glacial Termination, Science, 328, 1652-1656, doi:10.1126/science.1184119, 2010.

Dupont, L. M., Schlütz, F., Teboh Ewah, C., Jennerjahn, T. C., Paul, A., and Behling, H.: Two-step vegetation response to enhanced precipitation in Northeast Brazil during Heinrich event 1, Glob. Change Biol., 16, 1647-1660, 2009. 
Fanning, A. G. and Weaver, A. J.: On the role of flux adjustments in an idealized coupled climate model, Clim. Dynam., 13, 691-701, 1997.

González, C. and Dupont, L. M.: Tropical salt marsh succession as sea-level indicator during Heinrich events, Quaternary Sci. Rev., 28, 939-946, 2009.

González, C., Dupont, L. M., Behling, H., and Wefer, G.: Neotropical vegetation response to rapid climate changes during the last glacial period: Palynological evidence from the Cariaco Basin, Quaternary Res., 69, 217-230, 2008.

Grootes, P. M., Stuiver, M., White, J. W. C., Johnsen, S., and Jouzel, J.: Comparison of oxygen isotope records from the GISP2 and GRIP Greenland ice cores, Nature, 366, 552-554, 1993.

Handiani, D., Paul, A., and Dupont, L.: Tropical climate and vegetation changes during Heinrich Event 1: a model-data comparison, Clim. Past, 8, 37-57, doi:10.5194/cp-8-37-2012, 2012.

Harrison, S. P. and Prentice, I. C.: Climate and $\mathrm{CO}_{2}$ controls on global vegetation distribution at the last glacial maximum: analysis based on palaeovegetation data, biome modelling and palaeoclimate simulations, Glob. Change Biol., 9, 983-1004, 2003.

Heaney, L. R.: A synopsis of climatic and vegetational change in Southeast Asia, Climatic Change, 19, 53-61, doi:10.1007/BF00142213, 1991.

Heinrich, H.: Origin and consequences of cyclic ice rafting in the northeast Atlantic Ocean during the past 130,000 years, Quaternary Res., 29, 142-152, 1988.

Hessler, I., Dupont, L. M., Bonnefille, R., Behling, H., González, C., Helmens, K. F., Hooghiemstra, H., Lebamba, J., Ledru, M.-P., Lézine, A.-M., Maley, J., Marret, F., and Vincens, A.: Millennialscale changes in vegetation records from tropical Africa and South America during the last glacial, Quaternary Sci. Rev., 29, 2882-2899, doi:10.1016/j.quascirev.2009.11.029, 2010.

Kageyama, M., Combourieu Nebout, N., Sepulchre, P., Peyron, O., Krinner, G., Ramstein, G., and Cazet, J.-P.: The Last Glacial Maximum and Heinrich Event 1 in terms of climate and vegetation around the Alboran Sea: a preliminary model-data comparison, Comp. Rend. Geosci., 337, 983-992, 2005.

Kageyama, M., Mignot, J., Swingedouw, D., Marzin, C., Alkama, R., and Marti, O.: Glacial climate sensitivity to different states of the Atlantic Meridional Overturning Circulation: results from the IPSL model, Clim. Past, 5, 551-570, doi:10.5194/cp-5-5512009, 2009.

Kageyama, M., Paul, A., Roche, D. M., and Van Meerbeeck, C. J.: Modelling glacial climatic millennial-scale variability related to changes in the Atlantic meridional overturning circulation: a review, Quaternary Sci. Rev., 29, 2931-2956, 2010.

Kageyama, M., Merkel, U., Otto-Bliesner, B., Prange, M., AbeOuchi, A., Lohmann, G., Ohgaito, R., Roche, D. M., Singarayer, J., Swingedouw, D., and X Zhang: Climatic impacts of fresh water hosing under Last Glacial Maximum conditions: a multimodel study, Clim. Past, 9, 935-953, doi:10.5194/cp-9-9352013, 2013.

Kaplan, J. O., Bigelow, N. H., Bartlein, P. J., Christensen, T. R., Cramer, W., Harrison, S. P., Matveyeva, N. V., McGuire, A. D., Murray, D. F., Prentice, I. C., Razzhivin, V. Y., Smith, B., Walker, D. A., Anderson, P. M., Andreev, A. A., Brubaker, L. B., Edwards, M. E., Lozhkin, A. V., and Ritchie, J.: Climate change and Arctic ecosystems II: Modeling, palaeodatamodel comparisons, and future projections, J. Geophys. Res.,
108, 8171, doi:10.1029/2002JD002559, 2003.

Köhler, P., Joos, F., Gerber, S., and Knutti, R.: Simulated changes in vegetation distribution, land carbon storage, and atmospheric $\mathrm{CO}_{2}$ in response to a collapse of the North Atlantic thermohaline circulation, Clim. Dynam., 25, 689-708, 2005.

Ledru, M.-P., Campello, R. C., Landim-Dominguez, J. M., Martin, L., Mourguirat, P., Sifeddine, A., and Turcq, B.: Late-Glacial cooling in Amazonia inferred from pollen at Lagoa do Caçó, Northern Brazil, Quaternary Res., 55, 47-56, 2001.

Lee, S.-Y., Chiang, J. C. H., Matsumoto, K., and Tokos, K. S.: Southern Ocean wind response to North Atlantic cooling and the rise in atmospheric $\mathrm{CO}_{2}$ : Modeling perspective and paleoceanographic implications, Paleoceanography, 26, PA1214, doi:10.1029/2010PA002004, 2011.

Levis, S., Bonan, G. B, Vertenstein, M., and Oleson, K.: The Community Land Model's Dynamic Global Vegetation Model (CLMDGVM): Technical description and user's guide, NCAR Technical Note NCAR/TN-459+IA, doi:10.5065/D6P26W36, 2004.

McManus, J. F., François, R., Gherardi, J.-M., Keigwin, L. D., and Brown-Leger, S.: Collapse and rapid resumption of Atlantic meridional circulation linked to deglacial climate changes, Nature, 428, 834-837, 2004.

Meissner, K. J., Weaver, A. J., Matthews, H. D., and Cox, P. M.: The role of land surface dynamics in glacial inception: a study with the UVic Earth System model, Clim. Dynam., 21, 515-537, 2003.

Menviel, L., Timmermann, A., Mouchet, A., and Timm, O.: Meridional reorganizations of marine and terrestrial productivity during Heinrich events, Paleoceanography, 23, PA1203, doi:10.1029/2007PA001445, 2008.

Merkel, U., Prange, M., and Schulz, M.: ENSO variability and teleconnections during glacial climates, Quaternary Sci. Rev., 29, 86-100, 2010.

Mix, A., Bard, E., and Schneider, R.: Environmental processes of the ice age: land, oceans, glaciers (EPILOG), Quaternary Sci. Rev., 20, 627-657, 1999.

Morley, R. J.: Origin and Evolution of Tropical Forests, Wiley, Chichester, 2000.

Mulitza, S., Prange, M., Stuut, J.-B., Zabel, M., von Dobeneck, T., Itambi, A. C., Nizou, J., Schulz, M., and Wefer, G.: Sahel megadroughts triggered by glacial slowdowns of Atlantic meridional overturning, Paleoceanography, 23, PA4206, doi:10.1029/2008PA001637, 2008.

Niedermeyer, E. M., Prange, M., Mulitza, S., Mollenhauer, G., Schefuß, E., and Schulz, M.: Extratropical forcing of Sahel aridity during Heinrich stadials, Geophys. Res. Lett., 36, L20707, doi:10.1029/2009GL039687, 2009.

Oleson, K., Dai, Y., Bonan, G. B., Bosilovichm, M., Dickinson, R., Dirmeyer, P., Hoffman, F., Houser, P., Levis, S., Niu, G.-Y., Thornton, P., Vertenstein, M., Yang, Z., and Zeng, X.: Technical Description of the Community Land Model (CLM), NCAR Technical Note NCAR/TN-461+STR, doi:10.5065/D6N877R0, 2004.

Oleson, K. W., Niu, G.-Y., Yang, Z.-L., Lawrence, D. M., Thornton, P. E., Lawrence, P. J., Stockli, R., Dickinson, R. E., Bonan, G. B., Levis, S., Dai, A., and Qian, T.: Improvements to the Community Land Model and their impact on the hydrological cycle, J. Geophys. Res., 113, G01021, doi:10.1029/2007JG000563, 2008. 
Peltier, W. R.: Global Glacial Isostacy and the Surface of the Ice-Age Earth: The ICE-5G (VM2) Model and GRACE, Invited paper, Annu. Rev. Earth Planet. Sc., 32, 111-149, doi:10.1146/annurev.earth.32.082503.144359, 2004.

Peterson, L. C., Haug, G. H., Hughen, K. A., and Röhl, U.: Rapid changes in the hydrologic cycle of the tropical Atlantic during the last glacial, Science, 290, 1947-1951, 2000.

Poulter, B., Ciais, P., Hodson, E., Lischke, H., Maignan, F., Plummer, S., and Zimmermann, N. E.: Plant functional type mapping for earth system models, Geosci. Model Dev., 4, 993-1010, doi:10.5194/gmd-4-993-2011, 2011.

Prentice, J. C., Guiot, J., Huntley, B., Jolly, D., and Cheddadi, R.: Reconstructing biomes from palaeoecological data: a general method and its application to European pollen data at 0 and $6 \mathrm{ka}$, Clim. Dynam., 12, 185-194, 1996.

Roche, D. M., Dokken, T. M., Goosse, H., Renssen, H., and Weber, S. L.: Climate of the Last Glacial Maximum: sensitivity studies and model-data comparison with the LOVECLIM coupled model, Clim. Past, 3, 205-224, doi:10.5194/cp-3-205-2007, 2007.

Sarnthein, M., Winn, K., Jung, S. J. A., Duplessy, J. C., Labeyrie, L., Erlenkeuser, H., and Ganssen, G.: Changes in East Atlantic deep water circulation over the last 30,000 years: an eight timeslice record, Paleoceanography, 9, 209-267, 1994.

Schefuß, E., Kuhlmann, H., Mollenhauer, G., Prange, M., and Pätzold, J.: Forcing of wet phases in southeast Africa over the past 17,000 years, Nature, 480, 509-512, 2011.

Schurgers, G., Mikolajewicz, U., Gröger, M., Maier-Reimer, E., Vizcaíno, M., and Winguth, A.: Dynamics of the terrestrial biosphere, climate and atmospheric $\mathrm{CO}_{2}$ concentration during interglacials: a comparison between Eemian and Holocene, Clim. Past, 2, 205-220, doi:10.5194/cp-2-205-2006, 2006.

Sitch, S., Smith, B., Prentice, I. C., Arneth, A., Bondeau, A., Cramer, W., Kaplan, J. O., Levis, S., Lucht, W., Sykes, M. T., Thonicke, K., and Venevsky, S.: Evaluation of ecosystem dynamics, plant geography and terrestrial carbon cycling in the LPJ dynamic global vegetation model, Glob. Change Biol., 9, 161-185, 2003.

Stager, J. C., Ryves, D. B., Chase, B. M., and Pausata, F. S. R.: Catastrophic Drought in the Afro-Asian Monsoon Region During Heinrich Event 1, Science, 331, 6022, 1299-1302, doi:10.1126/science.1198322, 2011.

Stouffer, R. J., Yin, J., Gregory, J. M., Dixon, K. W., Spelman, M. J., Hurlin, W., Weaver, A. J., Eby, M., Flato, G. M., Hasumi, H., $\mathrm{Hu}$, A., Jungclaus, J. H., Kamenkovich, I. V., Levermann, A., Montoya, M., Murakami, S., Nawrath, S., Oka, A., Peltier, W. R., Robitaille, D. Y., Sokolov, A., Vettoretti, G., and Weber, S. L.: Investigating the causes of the response of the thermohaline circulation to past and future climate changes, J. Climate, 19, 1365-1387, 2006.
Thomas, D. S. G., Burrough, S. L., and Parker, A. G.: Extreme events as drivers of early human behaviour in Africa? The case for variability, not catastrophic drought, J. Quat. Sci., 27, 7-12, 2012.

Tjallingii, R., Claussen, M., Stuut, J. B., Fohlmeister, J., Jahn, A., Bickert, T., Lamy, F., and Röhl, U.: Coherent high- and lowlatitude forcing of the Northwest African humidity, Nat. Geosci., 1, 670-675, doi:10.1038/ngeo289, 2008.

Turney, C. S. M., Kershaw, A. P., Lowe, J. J., van der Kaars, S., Johnston, R., Rule, S., Moss, P., Radke, L., Tibby, J., McGlone, M. S., Wilmshurst, J., Vandergoes, M., Fitzsimons, S., Bryant, C., James, S., Branch, N. P., Cowley, J., Kalin, R. M., Ogle, N., Jacobsen, G., and Fifield, L. K.: Climate variability in the southwest Pacific during the Last Termination (20-10 kyr BP), Quaternary Sci. Rev., 25, 886-903, 2006.

Van der Kaars, S., Penny, D., Tibby, J. C., Fluin, J., Dam, R. A. C, and Suparan, P.: Late Quarternary palaeocology, palynology and palaeolimnology of a tropical lowland swamp: Rawa Danau, West-Java, Indonesia, Palaeogeogr. Palaeocl., 171, 185212, doi:10.1016/S0031-0182(01)00245-0, 2001.

Van der Kaars, W. A.: Palynology of eastern Indonesian marine piston-cores: A Late Quaternary vegetational and climatic record for Australia, Palaeogeogr. Palaeocl., 85, 239-302, 1991.

Vincens, A., Garcin, Y., and Buchet, G.: Influence of rainfall seasonality on African lowland vegetation during the Late Quaternary: pollen evidence from Lake Masoko, Tanzania, J. Biogeogr., 34, 1274-1288, 2007.

Wang, X., Aufer, A. S., Edwards, R. L., Cheng, H., Cristalli, P. S., Smart, P. L., Richards, D. A., and Shen, C.-C.: Wet periods in northeastern Brazil over the past $210 \mathrm{kyr}$ linked to distant climate anomalies, Nature, 432, 740-743, 2004.

Weaver, A. J., Eby, M., Wiebe, E. C., Bitz, C. M., Duffy, P. B., Ewen, T. L., Fanning, A. F., Holland, M. M., MacFadyen, A., Matthews, H. D., Meissner, K. J., Saenko, O., Schmittner, A., Wang, H., and Yoshimori, M.: The UVic Earth System Climate Model: model description, climatology, and applications to past, present and future climates, Atmos. Ocean, 39, 361-428, 2001.

Woillez, M.-N., Kageyama, M., Combourieu-Nebout, N., and Krinner, G.: Simulating the vegetation response in western Europe to abrupt climate changes under glacial background conditions, Biogeosciences, 10, 1561-1582, doi:10.5194/bg-10-1561-2013, 2013.

Yeager, S. G., Shields, C. A., Large, W. G., and Hack, J. J.: The low-resolution CCSM3, J. Climate, 19, 2545-2566, doi:10.1175/JCLI3744.1, 2006.

Zhou, H., Zhao, J., Feng, Y., Gagan, M. K., Zhou, G., and Yan, J.: Distinct climate change synchronous with Heinrich event one, recorded by stable oxygen and carbon isotopic compositions in stalagmites from China, Quaternary Res., 69, 306-315, doi:10.1016/j.yqres.2007.11.001, 2007. 